\title{
Molecular Defects of the Androgen Receptor
}

\author{
Michael J. McPhaul \\ Department of Internal Medicine, Division of Endocrinology and Metabolism, The University of \\ Texas Southwestern Medical School, Dallas, Texas 75390-8857
}

\begin{abstract}
Mutations in the androgen receptor (AR) gene cause a range of phenotypic abnormalities of male sexual development. At one end of the spectrum are individuals with complete androgen insensitivity (complete testicular feminization) who exhibit normal breast development and female external genitalia. At the other extreme are individuals with male phenotypes that are characterized by either subtle undervirilization or infertility. Studies in a number of different laboratories have identified mutations of the AR gene in subjects with androgen resistance syndromes. Defects that interrupt the AR open-reading frame have been traced to a number of distinct types of genetic alterations, have been identified in widely separated segments of the AR gene, and are invariably associated with the phenotype of complete androgen insensitivity. By contrast, mutations that cause single amino acid substitutions within the AR are localized to the DNA- or ligand-binding domains of the receptor protein and have been associated with the full range of androgen-resistant phenotypes. Regardless of the nature of the mutation, functional studies and assays of AR abundance suggest that the phenotypic abnormalities that result from mutation of the AR are the result of the impairment of receptor function, decreases in receptor concentration, or both.
\end{abstract}

\section{Background}

The description of androgen-resistant states built upon the recognition that endocrine disorders would likely result from abnormalities in the capacity of target tissues to respond appropriately to selected hormones (Albright, 1942). In 1953, Morris provided a detailed modern description of the syndrome that he termed testicular feminization, which he identified as a "recognizable syndrome found in patients who are essentially normal-appearing women, but who have undescended testes in place of ovaries" (Morris, 1953). Subsequent investigators presented evidence suggesting the insensitivity of end organs to the actions of androgens (Wilkins, 1957). Further investigators amassed information suggesting that distinct phenotypes might be the result of similar, but less severe, abnormalities (Reifenstein 1947, Rosewater et al., 1965; Morris and Mahesh, 1968) Careful endocrine studies, coupled with family studies, suggested that these syndromes were likely the result of variable defects of the same or similar genes (Wilson et al., 1974). 
Defects of the androgen receptor (AR) are common, compared to mutations of other members of the nuclear receptor family. In addition to the frequency of patients with clinical androgen resistance, the AR is unusual in the range of abnormal phenotypes that have been identified and traced to AR defects. Several features of the AR are believed to contribute to the frequency and diversity of the disorders that have been identified. First, the AR gene is located on the human X-chromosome (Migeon et al., 1981). For this reason, in normal 46,XY males, only a single copy of the AR gene is present. Consequently, any defect of function of the single AR gene present in normal genetic males and which is responsible for mediating the responses to androgen will result in an abnormality of male phenotypic development. Second, such defects of virilization are frequently evident at birth and thus are likely to precipitate investigations to determine their cause. Finally, even complete defects of the AR are compatible with life and individuals affected by such disorders are available for ascertainment.

\section{Classification on Clinical and Biochemical Grounds}

The phenotypic abnormalities that accompany androgen-resistant states can is be viewed as a continuum that relates directly to the extent to which the androgen-mediated processes of male sexual development have been disturbed. In patients in whom AR function is completely absent, none of the androgendependent internal or external male structures develop. By contrast, a range of intermediate phenotypes results in cases where AR function is partially preserved (Griffin, 1992; Quigley et al., 1995; Griffin et al., 2001). As was noted, these syndromes have been identified clinically using a variety of terms, including the Reifenstein syndrome, partial androgen insensitivity, and incomplete testicular feminization. Some authors have defined more-detailed systems with which to grade the degree of virilization in patients with partial forms of androgen insensitivity (Quigley et al., 1995).

In parallel with the recognition of the clinical syndromes, the study and diagnosis of AR defects was greatly aided by the development of methods to measure the intracellular protein that binds androgens with high affinity. These methods - applied to whole-cell and broken-cell assays - permitted the initial characterization of the receptor that mediated the actions of androgens and the definition of methods to measure and characterize the level and physical properties of this protein in tissues and in cells (Pinsky et al., 1981; Griffin and Durant, 1982; Brown et al., 1992). When applied to fibroblasts established from patients with these disorders, these techniques led to the recognition of a number of quantitative and qualitative abnormalities of androgen binding in patients with androgen resistance (Figure 1). 


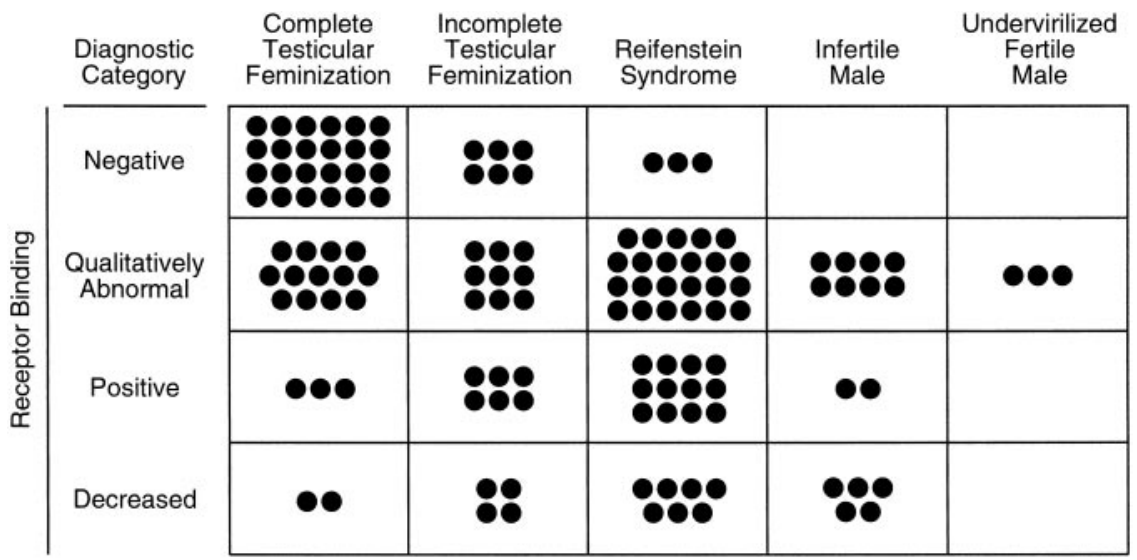

FIG. 1. Diagnostic and phenotypic categories of androgen resistance. Monolayer-binding assays were performed on genital skin fibroblasts established from individual subjects with varying degrees of androgen resistance. The samples were studied to assess the level and character of the androgen receptor (AR) expressed. "Qualitative binding abnormalities" denotes samples in which the level of AR detected was within the normal range but in which qualitative defects of androgen binding were detected (i.e., reduced affinity, accelerated ligand dissociation, thermal instability). While a preponderance of complete androgen resistance is associated with the absence of ligand binding (androgen binding negative), no direct relationship is evident between the type of ligand binding defect and the observed phenotype. [Reprinted with permission from Griffin JE 1992 Androgen resistance - the clinical and molecular spectrum. N Engl J Med 326:611-618. Copyright The Massachusetts Medical Society.]

Several features became apparent from such studies. First, the binding abnormalities fell into three broad categories: absent ligand binding, decreased levels of qualitatively normal ligand binding, and qualitative ligand-binding defects. In approximately $20 \%$ of patients in one series (Griffin et al., 2001), no quantitative or qualitative defect of the AR could be discerned. Second, such studies made it clear that although some types of defect were more frequent in some categories (e.g., a predominance of samples in which ligand binding was undetectable), no direct relationship existed between the clinical phenotype and the abnormality of ligand binding that was observed (Figure 1).

\section{Cloning and Structure of the Androgen Receptor}

Although progress in the characterization of many steroid receptors progressed rapidly in the 1970s and 1980s, the AR proved to be a difficult protein to purify. For this reason, specific antibodies were not available and information regarding the nature of the AR abnormalities causing the different states of $\mathrm{AR}$ 
resistance did not advance until the cloning of cDNAs encoding the AR (Chang et al., 1988; Lubahn et al., 1988; Faber et al., 1989; Tilley et al., 1989).

These studies revealed that the AR is a prototypic member of a large gene family: the nuclear receptor family (Mangelsdorf et al., 1995; Zoppi et al., in press). This family includes the classic steroid receptors as well as a large number of related proteins such as the receptors for thyroid hormone, vitamin D, and retinoic acid.

Members of this gene family possess a similar organization. Each protein contains a central DNA-binding domain and a carboxyl terminal ligand-binding domain (LBD). In addition, each predicted protein sequence contains an aminoterminal segment that is of variable length. This amino terminus is required for full transcriptional activity and is believed to represent the sites of important intramolecular and intermolecular contacts. In the case of the AR, the cDNAs isolated for the human AR predicted a protein approximately 917 amino acids long (Figure 2). In keeping with its large size, the human AR contains a large amino terminus that comprises nearly half of the molecule. Of interest, this amino-terminal segment contains three direct repeats of amino acid residues: one each containing glutamine, proline, and glycine residues. Expansion of the size

AR-A

AR-B 1

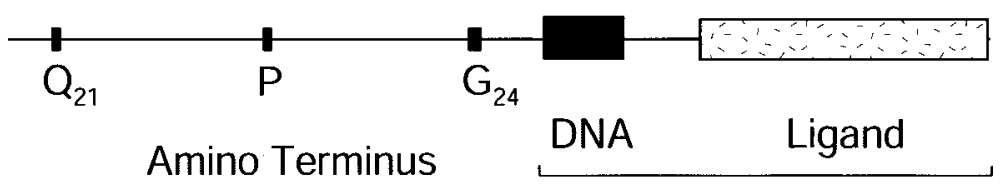

Binding Domains

FIG. 2. The predicted amino acid sequence of the human AR. The organization of the human AR is similar to that of the other nuclear receptors. The receptor contains a central DNA-binding domain (DBD) (residues 553-623) that mediates the high-affinity binding of the AR to target DNA sequences and a carboxyl terminal ligand-binding domain (LBD) (residues 692-919) that mediates the high-affinity binding of hormone. The amino terminus of the receptor comprises approximately half of the molecule (residues 1-550) and is required for full transcriptional activity (Gao et al., 1996). The predicted amino acid sequence of this segment of the human AR is unusual in that it contains three segments that are composed of direct repeats of single amino acid residues (homopolymeric repeats). These repeat elements, each located within the amino terminus of the protein, are not unique to the AR and have been identified in other transcription factors, including other members of the steroid receptor family. The amino acid coordinates employed here and throughout the text are those of Lubahn (Lubahn et al., 1988). 
of this glutamine homopolymeric segment has been associated with the pathogenesis of the spinal and bulbar muscular atrophy (Kennedy's disease) (La Spada et al., 1991).

\section{Mutations of the Androgen Receptor Gene and Androgen Resistance Syndromes}

As noted earlier, the AR was originally identified and characterized using assays to measure levels of tritiated androgen binding in intact cells and in cell homogenates. As the techniques to measure AR function and to identify mutations within the AR gene have become widely available, it has become possible to view the androgen-resistant states from perspectives that are more directly related to the effects that such mutations exert on receptor expression levels, structure, and function.

\section{A. INTERRUPTION OF THE ANDROGEN RECEPTOR OPEN-READING FRAME}

A number of different types of genetic defects can cause interruptions of the primary sequence of the human AR, including large- or small-scale deletions, insertions, and mutations that result in alterations of AR mRNA splicing. Although each of these mechanisms is the result of different genetic events, in each instance, the resulting mutant AR protein differs from the normal human $\mathrm{AR}$, either by premature truncation of the receptor protein or by the addition or removal of amino acids from the receptor sequence. As noted above, the critical hormone-binding and DNA-binding domains of the AR are localized to the carboxyl-terminus of receptor protein. For this reason, mutations that result in premature termination of the receptor have a dramatic effect on receptor function when introduced at virtually any position within the primary amino acid sequence, as these critical segments will be lacking. By contrast, alterations that serve to insert or remove single or multiple amino acids (small insertions or deletions) cause androgen resistance only when occurring within the DNA- or hormone-binding segments of the receptor protein (Figure 3).

\section{B. MUTATIONS IN THE DNA-BINDING DOMAIN OF THE ANDROGEN RECEPTOR}

In up to $20 \%$ of patients with clinical androgen resistance supported by endocrine studies or family histories consistent with a defect of the AR, abnormalities were not identified in monolayer assays of ligand binding by the AR (Griffin et al., 2001). AR gene structure from a number of such pedigrees has been analyzed. In most instances, amino acid substitutions have been detected within the DNA-binding domain of the AR. In studies by Zoppi (Zoppi et al., 


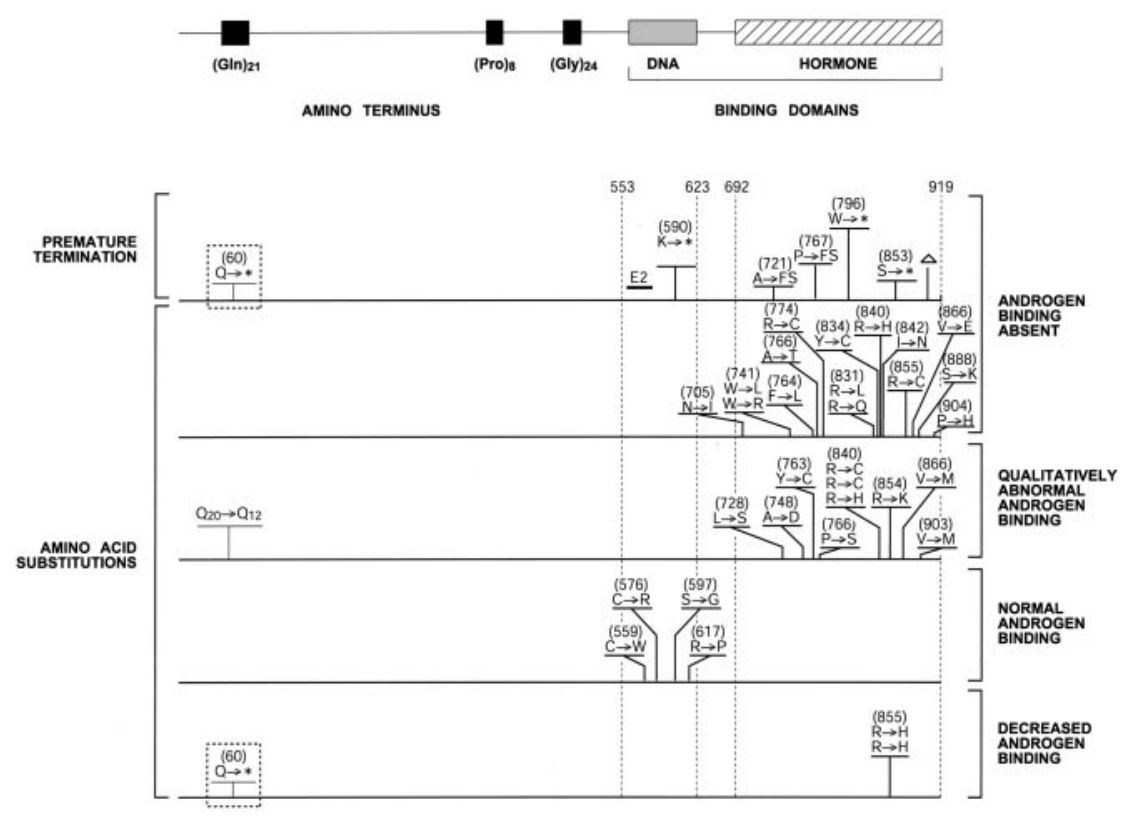

FIG. 3. Genetic mutations of the AR genes cause different abnormalities of androgen binding. The AR gene mutations identified in patients with androgen resistance exhibiting distinct abnormalities of androgen binding in genital skin fibroblast monolayer-binding assays are presented. Gene defects that interrupt the primary amino acid sequence of the AR are associated with the absence of androgen binding, whether caused by the insertion of premature termination codons, deletions, insertions, or alterations of AR mRNA splicing. Amino acid substitutions in specific segments of the AR LBD also can lead to the expression of undetectable androgen binding in genital skin fibroblast cultures, although, in most instances, the levels of immunoreactive AR are near normal (Avila et al., in press). Qualitative abnormalities of androgen binding are caused by amino acid substitutions in the LBD of the receptor protein. It is evident that the positions of the amino acid replacements causing absent androgen binding and qualitative defects are similar. It appears that the differences between these two categories reflect the degree to which the structure of the AR LBD is disrupted. Amino acid substitutions within the DBD of the AR are frequently identified in samples exhibiting normal levels of qualitatively normal androgen binding. Decreased levels of qualitatively normal androgen binding are traced to mutations that diminish the level of intact AR that is synthesized. The coordinates utilized in this figure and throughout the text are those of Lubahn (Lubahn et al., 1988). [Modified with permission from McPhaul MJ, Marcelli M, Zoppi S, Griffin JE, Wilson JD 1993 The spectrum of mutations in the androgen receptor gene that causes androgen resistance. J Clin Endocrinol Metab 76:17-23. Copyright The Endocrine Society.]

1992), amino acid substitutions were localized to critical residues within the DNA-binding domain of the AR in four unrelated subjects with complete or nearly complete forms of androgen resistance. Experiments examining the physical attributes of these mutant receptors in heterologous cells demonstrated that these mutant receptors bound ligand with normal or near-normal affinity, as 
was observed in fibroblast samples from the same patients. Although these studies confirmed the normal ligand-binding properties of the mutant receptors, transfection studies demonstrated that each was markedly impaired in terms of function. In vitro experiments to measure the capacity of the mutant ARs to bind to DNA showed that each was unable to bind normally to target DNA sequences. Similar results have been obtained in studies conducted in a number of different laboratories to analyze similar groups of patients with complete or partial forms of androgen resistance (Lumbroso et al., 1993; Mowszowicz et al., 1993; Sultan et al., 1993; Beitel et al., 1994b; De Bellis et al., 1994). These findings suggest that the AR defects in this patient group comprise a relatively homogeneous group from a mechanistic standpoint. Mutations of this type alter the structure of the DNA-binding domain of the receptor and interfere with the capacity of the receptor to recognize specific target DNA sequences.

\section{MUTATIONS IN THE LIGAND-BINDING DOMAIN OF THE ANDROGEN RECEPTOR}

Single amino acid substitutions in the LBD of the AR represent the most-frequent type of mutation that is identified in patients with androgen resistance. These individual amino acid replacements account for approximately $60 \%$ of the mutations identified in patients with clinical defects of androgen action and are most often the result of single nucleotide substitution mutations. Substitution mutations of the AR LBD have been identified in patients with the entire range of androgen-resistant phenotypes. The mutations can be divided into two categories, based on the effects on the binding of ligand in patient fibroblast samples: absence of detectable ligand binding and qualitative abnormalities of ligand binding.

\section{UNDETECTABLE LEVELS OF ANDROGEN BINDING IN FIBROBLAST MONOLAYER-BINDING ASSAYS}

Although identical when analyzed at the level of monolayer-binding assays (undetectable levels of androgen binding), amino acid substitution mutations in the LBD of the AR in this category are of two types. The first is less frequent and represents the replacement of amino acid residues in critical segments of the LBD. Amino acid substitutions of this type presumably induce major alterations of the structure of the LBD, to the extent that it is no longer capable of interacting with ligand. The mutant receptor described by Marcelli et al. (1994) is one well-characterized mutation of this type. As a result of this amino acid substitution (W741R), a hydrophobic residue within the amino terminal end of helix 5 is replaced that would be predicted to make important contacts with the $\mathrm{C}$ ring of testosterone (Mathias et al., 2000; McPhaul, 2000). In addition to the steric effects that such changes might be expected to exert, the introduction of such a 
charged residue into this hydrophobic region of the LBD is likely to have dramatic effects on the tertiary structure of the ligand-binding pocket. In functional analyses, mutant ARs of this type cannot bind hormone and cannot activate model reporter genes, even when expressed in heterologous cells (Marcelli et al., 1994).

Mutant ARs that are completely incapable of binding hormone when assayed following expression in heterologous cells are uncommon. More frequently, when cDNAs encoding such mutant ARs are created and expressed in heterologous cells, they are found to be capable of binding hormone. For example, one strain (strain 105) was categorized originally as ligand-binding negative, based on monolayer ligand-binding assay results. Analysis of the AR gene in this subject revealed a single amino acid substitution (R774C). When cDNAs encoding this mutant receptor were expressed in heterologous cells, however, ligand binding was easily measurable, although altered kinetics and stability were evident (Marcelli et al., 1991). Additional mutant receptors have been described that display similar properties: 1) relatively normal or near-normal levels of immunoreactive receptor, 2) markedly diminished levels of ligand binding, and 3) measurable levels of ligand binding when expressed in heterologous cells. These discrepancies likely reflect differences in the level of expression and the sensitivity of the assays that are employed to analyze the samples.

\section{E. QUALITATIVE LIGAND-BINDING ABNORMALITIES}

Analysis using monolayer-binding assays of the AR present in fibroblast samples from individuals with androgen resistance believed due to AR defects demonstrated normal levels of androgen binding. When fibroblasts from some of these patients were analyzed carefully, discernible differences could be identified when qualitative tests of ligand binding were applied. Such tests included measurements of the affinity of ligand binding, the rapidity with which ligand dissociates from the receptor (accelerated ligand dissociation), and increased susceptibility to thermal denaturation.

With very few exceptions, the naturally occurring mutations causing qualitative abnormalities of ligand binding are single amino acid substitutions localized to the hormone-binding domain of the receptor protein. Furthermore, the distribution of the amino acid substitutions identified in ARs exhibiting qualitative abnormalities of ligand binding is similar to that of amino acid replacements identified in strains in which no androgen binding is detected (McPhaul et al., 1992). This observation suggests that the type of binding abnormality that is observed is related directly to the degree that the structure of the ligand-binding domain is disrupted. Findings from the study of mutant receptors from pedigrees in which the same amino acid has been mutated to 
different residues have supported this concept. This concept is most evident in the work of Prior, in which replacement of arginine 774 by cysteine residue leads to androgen resistance and undetectable ligand binding in patient fibroblasts (Prior et al., 1992). Substitution of the same residue by histidine, a more conservative amino acid replacement, leads to normal levels of androgen binding in fibroblasts that displays a marked thermal lability in in vitro assays. Additional pedigrees have been described in which different amino acid substitution mutations at a single residue have differing effects on the binding of ligand by the receptor, depending of the nature of the amino acid substitution (Ris-Stalpers et al., 1991; Kazemi-Esfarjani et al., 1993; Beitel et al., 1994a).

The analysis of mutant ARs in assays is straightforward when the receptor protein possesses little or no functional activity. The assessment of qualitatively abnormal ARs is considerably more difficult, as mutant receptors of this class are capable of binding ligand with varying affinity and stability. In this context, the cellular environment and the specific ligands will exert important effects on the results of assays performed to analyze AR function. The work of Marcelli clearly demonstrated this effect (Marcelli et al., 1994). These investigators examined the properties of a range of mutant ARs that carried different amino acid substitution mutations in the hormonebinding domain. The responsiveness of these ARs was examined using several agonist ligands, including 5 alpha dihydrotestosterone (DHT), testosterone $(\mathrm{T})$, and mibolerone. The experiments were performed using transfection assays in a cell strain in which the metabolism of testosterone and 5 alpha dihydrotestosterone is rapid, similar to the degradation of androgen that occurs in most mammalian androgen target tissues. Results of these experiments varied, depending on the type of ligand employed. When physiologic androgens (e.g., testosterone, dihydrotestosterone) were used to stimulate the mutant receptors, greater deficiencies of function were observed for most of the mutant receptors. In each instance, the nonmetabolizable androgen, mibolerone, was observed to be more potent than either of the two androgens that were subject to metabolic inactivation. The relative ineffectiveness of $T$ and DHT in these experiments could be overcome by repeated additions of these hormones during the course of the hormone stimulation. These results suggested that the stability of the hormone-receptor complexes plays a critical role in the function of the AR and that AR mutations that destabilize the hormone-receptor complex will have a major effect on receptor activity. These results also demonstrate that the environment in which AR function is assessed can have an important modifying influence on the levels of function that are observed, particularly in response to physiologic, metabolizable androgens. These results also indicate that mutant receptors that display qualitative abnormalities of ligand binding can be manipulated pharmacologically. Consistent with this concept, biological responses have been observed 
to the administration of supraphysiologic levels of androgen (Grino et al., 1989; Tincello et al., 1997).

\section{F. ANDROGEN RECEPTOR MUTATIONS CAUSING DECREASED LEVELS OF LIGAND BINDING}

It appears that the types of mutations identified in this category will be quite heterogeneous and reflect alterations that affect how much AR protein is synthesized.

The first mutation of this class was discovered during the analysis of the AR genes of affected subjects in a pedigree with complete androgen insensitivity. While monolayer-binding assays of fibroblasts established from affected individuals demonstrated measurable, but reduced, levels of a qualitatively normal AR protein, immunoblots were unable to detect immunoreactive AR using an antibody directed at the amino terminus of the AR. Sequence analysis of the AR gene from affected individuals in this pedigree revealed a single-nucleotide substitution that resulted in the insertion of a premature termination codon in place of amino acid residue 60 (Zoppi et al., 1993). Subsequent analyses using antibodies directed at epitopes within the amino terminus revealed that a smaller form of the AR was synthesized in fibroblasts from affected individuals in this pedigree, accounting for the residual ligand binding that was detected in monolayer-binding assays. More recent studies have established that this shortened form of the AR (termed AR-A, on the basis of its similarity to the A-form of the progesterone receptor) is synthesized by internal initiation at methionine 189 and is expressed at low levels in normal fibroblasts and tissues (Wilson and McPhaul, 1994,1996). Transfection experiments demonstrated that this AR-A isoform displays subtle differences in function on selected response elements (Gao and McPhaul, 1998).

The studies of Choong et al. (1996) suggest a somewhat-different mechanism mutation leading to a phenotype of partial androgen insensitivity syndrome (AIS). Analysis of the AR gene in affected subjects identified a single-nucleotide substitution that altered the second amino acid residue (lysine residue in place of the normal aspartate residue) of the AR open-reading frame. Although it was not possible to examine the effects of this mutation in cultured fibroblasts from affected individuals in this pedigree, experiments employing the expression of cDNAs encoding the mutant AR in heterologous cells suggested that the AIS phenotype was caused primarily by the reduced levels of AR expressed due to reduced efficiency of translational initiation.

Additional studies have suggested that alterations in the synthesis of normal AR mRNA can lead to reduced levels of functional AR protein. In the studies reported by Sammarco (Sammarco et al., 2000), partial androgen insensitivity was associated with reduced levels of apparently normal AR. Analysis of the AR 
gene in this individual identified an alteration at position +5 of the donor splice site at the junction between exon 6 and intron 6. Analysis of the AR mRNA expressed in cells from the affected individual demonstrated that intron 6 was retained in a large proportion of the AR mRNA. Immunoblot analysis revealed only a small quantity of intact AR. A similar mechanism was proposed to account for the androgen resistance observed in a patient with the Reifenstein phenotype (Ris-Stalpers et al., 1994).

\section{G. CLINICAL PHENOTYPE AND LOSS-OF-FUNCTION MUTATIONS OF THE ANDROGEN RECEPTOR}

The number of AR gene mutations that have been analyzed permits general conclusions regarding the nature of the relationship between clinical phenotype and AR mutation. First, mutations that interrupt the AR open-reading frame whether caused by premature termination, aberrant splicing, or deletion of partial or complete exon segments - are associated with a phenotype of complete androgen resistance. This relationship is the result of the locations of the DNA- and hormone-binding domains at the carboxyl terminus of the AR protein. As a consequence, alterations that truncate the receptor protein at any point during its synthesis will remove portions of one or both of these important functional domains.

In contrast to mutations that interrupt the AR open-reading frame, amino acid substitutions within the AR sequence are capable of causing all androgenresistant phenotypes. The degree of clinical resistance observed does not appear to correlate with the nature or location of specific mutation. Instead, the phenotype appears to reflect the level of residual AR function that is expressed in the androgen target tissues. In different instances, this diminished level of function may be caused by alterations in the functional capacity of the receptor protein, its level of expression, or combinations of both factors.

\section{ACKNOWLEDGMENTS}

The original work described herein was supported by National Institutes of Health grant 32820 and by grant I-1090 from the Robert A. Welch Foundation.

\section{REFERENCES}

Albright F, Burnett CH, Smith PH, Parson W 1942 Pseudo-hypoparathyroidism - an example of the "Seabright Bantam Syndrome." Endocrinology 30:922-932

Avila DM, Wilson CM, Nandi N, Griffin JE, Wilson JD, McPhaul MJ 2002 Immunoreactive androgen receptor (AR) in genital skin fibroblasts from subjects with androgen resistance and undetectable levels of AR in ligand binding assays. J Clin Endocrinol Metabol, in press

Beitel LK, Kazemi-Esfarjani P, Kaufman M, Lumbroso R, DiGeorge AM, Killinger DW, Trifiro MA, Pinsky L 1994a Substitution of arginine-839 by cysteine or histidine in the 
androgen receptor causes different receptor phenotypes in cultured cells and coordinate degrees of clinical androgen resistance. J Clin Invest 94:546-554

Beitel LK, Prior L, Vasiliou DM, Gottlieb B, Kaufman M, Lumbroso R, Alvarado C, McGillivray B, Trifiro M, Pinsky L 1994b Complete androgen insensitivity due to mutations in the probable alpha-helical segments of the DNA-binding domain in the human androgen receptor. Hum Mol Genet 3:21-27

Brown TR, Maes M, Rothwell SW, Migeon CJ 1982 Human complete androgen insensitivity with normal dihydrotestosterone receptor binding capacity in cultured genital skin fibroblasts: evidence for a qualitative abnormality of the receptor. J Clin Endocrinol Metabol 55:61-69

Chang CS, Kokontis J, Liao ST 1988 Structural analysis of complementary DNA and amino acid sequences of human and rat androgen receptor. Proc Natl Acad Sci USA 85:7211-7215

Choong CS, Quigley CA, French FS, Wilson EM 1996 A novel missense mutation in the amino-terminal domain of the human androgen receptor gene in a family with partial androgen insensitivity syndrome causes reduced efficiency of protein translation. J Clin Invest 98:1423-1431

De Bellis A, Quigley CA, Marschke KB, el-Awady MK, Lane MV, Smith EP, Sar M, Wilson EM, French FS 1994 Characterization of mutant androgen receptors causing partial androgen insensitivity syndrome. J Clin Endocrinol Metab 78:513-522

Faber PW, Kuiper GG, van Rooij HC, van der Korput JA, Brinkmann AO, Trapman J 1989 The N-terminal domain of the human androgen receptor is encoded by one, large exon. Mol Cell Endocrinol 61:257-262

Gao TS, McPhaul MJ 1998 Functional activities of the A- and B-forms of the human androgen receptor in response to androgen receptor agonists and antagonists. Mol Endocrinol 12:654663

Gao TS, Marcelli M, McPhaul MJ 1996 Transcriptional activation and transient expression of the human androgen receptor J Steroid Biochem Mol Biol 59:9-20

Griffin JE 1992 Androgen resistance - the clinical and molecular spectrum. N Engl J Med 326:611-618

Griffin JE, Durrant JL 1982 Qualitative receptor defects in families with androgen resistance: failure of stabilization of the fibroblast cytosol androgen receptor. J Clin Endocrinol Metab 55:465-474

Griffin JE, McPhaul MJ, Russell DW, Wilson JD 2001 The androgen resistance syndromes: steroid 5-reductase 2 deficiency, testicular feminization, and related disorders. In: Scriver CR, Beaudet AL, Sly WS, Valle D, eds. The Metabolic and Molecular Bases of Inherited Disease, 8th edit. New York: McGraw-Hill; 4117-4146

Grino PB, Isidro-Gutierrez RF, Griffin JE 1989 Androgen resistance associated with a qualitative abnormality of the androgen receptor and responsive to high dose androgen therapy. J Clin Endocrinol Metab 68:578-584

Kazemi-Esfarjani P, Beitel LK, Trifiro M, Kaufman M, Rennie P, Sheppard P, Matusik R, Pinsky L 1993 Substitution of valine-865 by methionine or leucine in the human androgen receptor causes complete or partial androgen insensitivity, respectively with distinct androgen receptor phenotypes. Mol Endocrinol 7:37-46

La Spada AR, Wilson EM, Lubahn DB, Harding AE, Fischbeck KH 1991 Androgen receptor gene mutations in X-linked spinal and bulbar muscular atrophy. Nature 352:77-79

Lubahn DB, Joseph DR, Sar M, Tan J, Higgs HN, Larson RE, French FS, Wilson EM 1988 The human androgen receptor: complementary deoxyribonucleic acid cloning, sequence analysis and gene expression in prostate. Mol Endocrinol 2:1265-1275

Lumbroso S, Lobaccaro JM, Belon C, Belon C, Martin D, Chaussain JL, Sultan C 1993 A new mutation within the deoxyribonucleic acid-binding domain of the androgen receptor gene in a family with complete androgen insensitivity syndrome. Fertil Steril 60:814-819 
Mangelsdorf DJ, Thummel C, Beato M, Herrlich P, Schutz G, Umesono K, Blumberg B, Kastner P, Mark M, Chambon P 1995 The nuclear receptor superfamily: the second decade. Cell 83:835-839

Marcelli M, Tilley WD, Zoppi S, Griffin JE, Wilson JD, McPhaul M 1991 Androgen resistance associated with a mutation of the androgen receptor at amino acid 772 (Arg $\rightarrow$ Cys) results from a combination of decreased messenger ribonucleic acid levels and impairment of receptor function. J Clin Endocrinol Metab 73:318-325

Marcelli M, Zoppi S, Wilson CM, Griffin JE, McPhaul MJ 1994 Amino acid substitutions in the hormone-binding domain of the human androgen receptor alter the stability of the hormone receptor complex. J Clin Invest 94:1642-1650

Matias PM, Donner P, Coelho R, Thomaz M, Peixoto C, Macedo S, Otto N, Joschko S, Scholz P, Wegg A, Basler S, Schafer M, Egner U, Carrondo M 2000 Structural evidence for ligand specificity in the binding domain of human androgen receptor. Implications for pathogenic gene mutations. J Biol Chem 275:26164-26171

McPhaul MJ 2000 The androgen receptor in syndromes of androgen insensitivity and in prostate cancer. In: Shupnik, MA, ed. Gene Engineering and Molecular Models in Endocrinology. Totowa, NJ: Humana Press; 339-372

McPhaul MJ, Marcelli M, Zoppi S, Wilson CM, Griffin JE, Wilson JD 1992 Mutations in the ligand-binding domain of the androgen receptor gene cluster in two regions of the gene. J Clin Invest 90:2097-2101

McPhaul MJ, Marcelli M, Zoppi S, Griffin JE, Wilson JD 1993 The spectrum of mutations in the androgen receptor gene that causes androgen resistance. J Clin Endocrinol Metab 76:17-23

Migeon BR, Brown TR, Axelman J, Migeon CJ 1981 Studies of the locus for androgen receptor: localization on the human X chromosome and evidence for homology with the Tfm locus in the mouse. Proc Natl Acad Sci USA 78:6339-6343

Morris JM 1953 The syndrome of testicular feminization in male pseudohermaphrodites. Am J Obstet Gynecol 65:1192-1211

Morris JM, Mahesh VB 1968 Further observations on the syndrome, "testicular feminization." Am J Obstet Gynecol 87:731-748

Mowszowicz I, Lee HJ, Chen HT, Mestayer C, Portois MC, Cabrol S, Mauvais-Jarvis P, Chang C 1993 A point mutation in the second zinc finger of the DNA-binding domain of the androgen receptor gene causes complete androgen insensitivity in two siblings with receptorpositive androgen resistance. Mol Endocrinol 7:861-869

Pinsky L, Kaufman M, Summitt RL 1981 Congenital androgen insensitivity due to a qualitatively abnormal androgen receptor. Am J Med Genet 10:91-99

Prior L, Bordet S, Trifiro MA, Mhatre A, Kaufman M, Pinsky L, Wrogeman K, Belsham DD, Pereira F, Greenberg C 1992 Replacement of arginine 773 by cysteine or histidine in the human androgen receptor causes complete androgen insensitivity with different receptor phenotypes. Am J Hum Genet 51:143-155

Quigley CA, De Bellis A, Marschke KB, el-Awady MK, Wilson EM, French FS 1995 Androgen receptor defects: historical, clinical, and molecular perspectives. Endocr Rev 16:271-321

Reifenstein EC 1947 Hereditary familial hypogonadism. Proc Am Fed Clin Res 3:86

Ris-Stalpers C, Trifiro MA, Kuiper GG, Jenster G, Romalo G, Sai T, van Rooij HC, Kaufman M, Rosenfield RL, Liao S 1991 Substitution of aspartic acid-686 by histidine or asparagine in the human androgen receptor leads to a functionally inactive protein with altered hormone-binding characteristics. Mol Endocrinol 5:1562-1569

Ris-Stalpers C, Verleun-Mooijman MC, de Blaeij TJ, Degenhart HJ, Trapman J, Brinkmann AO 1994 Differential splicing of human androgen receptor pre-mRNA in X-linked Reifenstein syndrome, because of a deletion involving a putative branch site. Am J Hum Genet $54: 609-617$ 
Rosewater S, Gwinup G, Hamwi GJ 1965 Familial gynecomastia. Ann Intern Med 63:377-385

Sammarco I, Grimaldi P, Rossi P, Cappa M, Moretti C, Frajese G, Geremia R 2000 Novel point mutation in the splice donor site of exon-intron junction 6 of the androgen receptor gene in a patient with partial androgen insensitivity syndrome. J Clin Endocrinol Metab 85:32563261

Sultan C, Lumbroso S, Poujol N, Belon C, Boudon C, Lobaccaro JM 1993 Mutations of androgen receptor gene in androgen insensitivity syndromes. J Steroid Biochem Mol Biol 46:519-530

Tilley WD, Marcelli M, Wilson JD, McPhaul MJ 1989 Characterization and expression of a cDNA encoding the human androgen receptor. Proc Natl Acad Sci USA 86:327-331

Tincello DG, Saunders PT, Hodgins MB, Simpson NB, Edwards CR, Hargreaves TB, Wu FC 1997 Correlation of clinical, endocrine and molecular abnormalities with in vivo responses to high-dose testosterone in patients with partial androgen insensitivity syndrome. Clin Endocrinol 46:497-506

Wilkins L 1957 Abnormal sex differentiation: hermaphroditism and gonadal dysgenesis. In: The Diagnosis and Treatment of Endocrine Disorders in Childhood and Adolescence. Springfield, IL: Charles C. Thomas; 258

Wilson CM, McPhaul MJ 1994 A and B forms of the androgen receptor are present in human genital skin fibroblasts. Proc Natl Acad Sci USA 91:1234-1238

Wilson CM, McPhaul MJ 1996 A and B forms of the androgen receptor are expressed in a variety of human tissues. Mol Cell Endocrinol 120:51-57

Wilson JD Harrod MJ Goldstein JL Hemsell DL MacDonald PC 1974 Familial incomplete male pseudohermaphroditism, type 1. Evidence for androgen resistance and variable clinical manifestations in a family with the Reifenstein syndrome. N Engl J Med 290:1097-1103

Zoppi S, Marcelli JP, Griffin JE, Deslypere JP, Wilson JD, McPhaul M 1992 Amino acid substitutions in the DNA-binding domain of the human androgen receptor are a frequent cause of receptor-binding positive androgen resistance. Mol Endocrinol 6:409-415

Zoppi S, Wilson CM, Harbison MD, Griffin JE, Wilson JD, McPhaul MJ, Marcelli M 1993 Complete testicular feminization caused by an amino-terminal truncation of the androgen receptor with downstream initiation. J Clin Invest 91:1105-1112

Zoppi S, Young M, McPhaul MJ 2002 Regulation of gene expression by the nuclear receptor family. In: Mason JI, ed. The Genetics of Steroid Biosynthesis. London: Taylor \& Francis Publishing Group; in press 